\title{
An Operational Definition of Effective Leadership: Was Covey Right?
}

\section{David Spohn*}

Department of Finance, Warrington College of Business Administration, University of Florida, Gainesville, FL, USA

\begin{abstract}
Given the recent discussion of leadership, specifically in Public Administration, this brief overview compares ideas proposed by Stephen R. Covey in his 1989 book entitled, The 7 Habits of Highly Effective People to current literature of leadership theory. A current perspective on these habits is the focus. No evidence is found in contrast to Covey's suggested habits as compared to ethical leadership theory, authentic leadership theory, transformational leadership theory, servant leadership theory, and leader-member exchange theory, and it remains a recommended reference for effective leadership.
\end{abstract}

Keywords: Leadership; Public administration; Management

\section{Introduction}

The path of effective leadership is filled with theories and studies regarding different types of leaders, different characteristics of leaders, and subsequent traits associated with effective leaders. Some argue there are a set of characteristics and traits that are universally acceptable [1]. Kirkpatrick and Locke [2] suggest leaders are inherently a different breed, and the traits they exhibit are universally applicable to all types of environments. Contrary to this thought, Tannenbaum and Schmidt [3] suggest there is not a 'one size fits all' solution; rather, effective leadership characteristics are dependent on the situation, environment, and life cycle of the business or organization. Goleman [4] also suggests an effective leader will adapt traits or characteristics of leadership to the context within which he or she operates. Podsakoff [5] even found leaders or supervisors are perceived as possessing different characteristics by different employees. All of this suggests the literary research has not found one best solution to defining an effective leader.

It is generally accepted that leaders (whether effective or ineffective) influence followers affecting their lives either negatively or positively [6]. Leaders inherently have more power, which gives them more influence [7]. This added influence over followers carries a greater responsibility of the impact on followers, and thus leaders become instrumental in developing and establishing organizational goals and values. The importance of effective leadership is not a source of debate, but rather understanding those characteristics, traits, or habits of individuals becomes central to the ongoing addition to the literature and study of the topic.

There are numerous leadership styles and characteristics such as transformational/charismatic leadership (style), or honesty (characteristics), but none are broad enough to encompass all that a leader is seen to be (Brown, Trevino, and Harrison [8]). Given the many ideas of leadership, there is still much debate as to whether leaders are born or made. This type of debate is outside the scope of this paper, but it is worth noting the importance and continued discussion within the literature regarding this thought. Further, Judge, Bono, Illies and Gerhardt [9] provided evidence that certain leadership traits are associated with effective leadership.

Covey [10] in his work, The 7 Habits of Highly Effective People avoids the debate of whether characteristics or traits are inherent in effective leaders, rather focusing on habits effective leaders should have or are practicing to become effective, remain effective or sustain effectiveness.

\section{Literature Review}

This review attempts to compare Covey's identified seven habits of effective leaders to the current literature on leadership related to each of the habits highlighting the value of each.
Covey thus identifies the seven habits of highly effective people as:

Habit 1: Be proactive.

Habit 2: Begin with the end in mind.

Habit 3: Put first things first.

Habit 4: Think win/win.

Habit 5: Seek first to understand, then to be understood.

Habit 6: Synergize.

Habit 7: Sharpen the saw.

\section{Habit 1: Be proactive-principles of personal vision}

Covey [10] makes a clear distinction in defining 'proactivity.' In his use and understanding of the first habit, he is careful to emphasize that being proactive is much more than the general understanding of an individual taking initiative. Rather, Covey defines it as taking responsibility of one's own life and is indicative as a behavioral function of decisions. Everyone is given the responsibility as an initiator to make things happen. He goes on to define 'responsibility' as being able to choose a response to a given situation. Conceptually, Covey draws a very clear line between those who are 'proactive' versus those who are 'reactive.' The key difference is proactive people chose how they will respond to any given situation or circumstance (effective), whereas those who are reactive let circumstances dictate outcomes (ineffective). Noting the difference between effective and ineffective leaders, it is also important to understand the difference between the two does not preclude environmental factors, as both are equally influenced. However, effective leaders' response to those factors outside of their control are based on internal values or responses. Ultimately, Covey [10] is emphasizing that as an effective leader practicing proactivity, the individual takes charge of his or her own destination.

Stogdill [11] suggests that all leaders inherently display certain characteristics of cognitive ability, courage, drive, honesty, integrity,

*Corresponding author: David Spohn, Department of Finance, Warrington College of Business Administration, University of Florida, Gainesville, FL 32611, USA, Tel: + 8136856539; E-mail: dspohn.ds@gmail.com

Received June 26, 2018; Accepted June 30, 2018; Published July 05, 2018

Citation: Spohn D (2018) An Operational Definition of Effective Leadership: Was Covey Right?. Review Pub Administration Manag 6: 251. doi:10.4172/23157844.1000251

Copyright: @2018 Spohn D. This is an open-access article distributed under the terms of the Creative Commons Attribution License, which permits unrestricted use, distribution, and reproduction in any medium, provided the original author and source are credited. 
motivation, and self-confidence. Lord et al. [1] conclude the same. While many of these characteristics are important, and may very well be generalized across leaders, Covey focuses on one of these characteristics in his first habit of proactivity. Similarly, the literature supports this in Stogdill [11] and Lord et al.'s [1] findings of drive and motivation. Extant literature also lends support to this habit $[2,12-14]$ as prominent traits of leaders. These two characteristics or habits as Covey conveys, are what defines proactivity, along with the trait of responsibility. However, this is only supported in two of the central leadership theories (ethical leadership theory and transformational leadership theory).

\section{Habit 2: Begin with the end in mind-principles of personal leadership}

Covey's second habit [10] is a visualization exercise where he encourages individuals to begin an event at the destination. His thought process includes glancing into the future to understand where you want to be before you start the decision or decisions that will affect an individual's path. This has many beneficial characteristics, as beginning at the destination helps the individual grasp the beginning point, understand where the individual currently resides in the decision process (and understanding surroundings), and gives the individual a path to follow, ensuring success throughout each decision point. Covey's argument for this habit resides in the fact that as people become busy with normal happenings or unusual circumstances, it is often very easy to become distracted with the almost infinite variables that could change an individual's course. These distractions become active actions that mislead and are contrary to interests or intentions of the ultimate goal. This visionary exercise becomes a key determinant in accomplishing goals, and an effective measure of success. As a proponent of this principle, the first step in 'creation' is to mentally grasp the outcome.

As a component of transformational leadership theory, the leader and follower share a relationship built on trust [15]. In placing their trust in the leader, the subordinate also places a considerable amount of confidence in their leader [16]. Bass [17] suggests that charisma, individual consideration, inspiration, and intellectual stimulation as the four key components of a transformational leader. This idea of inspiration (from the leader to the follower) is realized through the ability to relate an idea or end state. The ability to influence the follower through inspiration is predicated through the leader's visionary prowess [17]. Because vision is a key concept of leadership [18-25], leaders are thus forced to take an abstract idea in their minds and incorporate those ideas to others [26], giving Covey's second habit legitimacy. In addition to transformational leadership theory, servant leadership theory also supports this idea through leader foresight [27].

\section{Habit 3: Put first things first-principles of personal manage- ment}

Covey's [10] second habit is to first use imagination, then to visualize. His third habit is the realization of that imagination. He stresses this habit is responsible for the actual creation of the visualization. Building on the two previous habits, Covey emphasizes the individual's propensity to take control, conceptually understand where he/she is going, and the third step of actualization revolves around prioritizing or managing an individual's self. To accomplish goals, Covey suggests a systematic way to reduce time with 'not urgent' and 'not important' tasks that inherently present themselves throughout each day or week. Prioritizing time spent with 'urgent' and 'important' tasks each week will inevitably free an individual by 'putting first things first' which leads an individual down the path to effectiveness.
Being able to prioritize based on a Covey's quadrant means delegation of certain tasks to others to ensure effectiveness. Yukl [28] seems to agree, as his research found among others, that participative behaviors including delegation of authority, setting expectations of performance and facilitation of decision making all are behaviors in which leaders display.

Ashley and Patel [29] find leadership who focus on total quality or efficiency is a significant factor in determining successful company performance. They further emphasize leaders who focus on communication as well as quality produce successful firms. This is an important concept that falls in line with Covey. The habit of 'putting first things first' is just another way to define efficiency, as Covey emphasizes reducing time wasted on 'not urgent' and 'not important' tasks. This focus inevitably becomes centered on efficiency or time spent on meaningful tasks, which inherently leads to effectiveness.

Several leadership theories also elude to the importance of priority as in leader-member exchange theory and servant leadership theory $[30,31]$. While neither theory inherently addresses priority in the way that Covey suggests (setting priorities for efficiency), both theories share it as a construct in the relationship between leader and follower [32]. Additional studies show this increase in prioritization aid in departmental success [33].

\section{Habit 4: Think win/win-principles of interpersonal leadership}

Given the unique relationship between leader and follower, leaders have influence over those who follow them [6]. This influence becomes central to Covey's [10] fourth habit. Being in a leadership role has many advantages and responsibilities. One of those responsibilities under Covey's habit is under the dichotomy of moving from independence to interdependence. This interdependence of a leader and follower involves the idea of an effective interpersonal relationship. The responsibility of the leader then becomes to 'think win/win.' Covey emphasizes this mentality (or habit) is one of six different decisions encompassing: Win/Win, Win/Lose, Lose/Win, Lose/Lose, Win, and Win/Win or No Deal. Covey goes on to argue that Win/Win is a simple frame of mind that seeks solutions which are mutually beneficial to all parties involved. Decisions or circumstances that preclude the Win/Win solution become predicated on an abuse of power or position. Decisions made on principle become central to the success of all parties involved and are generally viewed as mutually beneficial. This idea eliminates the success of one at another's expense. Rather, it is a method, effective leaders use to enhance the capabilities of those surrounding them.

Obviously, there are many skills effective leaders need to be successful, but interpersonal skills are extremely important, as supported in ethical leadership theory, authentic leadership theory, transformational leadership theory, servant leadership theory and leader-member exchange theory. Covey makes it inherently clear that in order to think Win/Win, interpersonal skills of a leader are essential. Yukl [28] also agrees and concludes interpersonal and conceptual skills are inherent traits of an effective leader, as well as technical skills.

In considering a Win/Win scenario as Covey suggests, leaders and followers look to exercise a mutually beneficial arrangement. Pettigrew [34] coffers an example where leaders should look to leverage this mentality when controlling a piece of vital information (shared). Mechanic [35] also supports this concept in suggesting a follower utilizing a specialized skill set to solve organizational issues. Both examples follow the concept labeled as transactional leadership theory, but nonetheless are key components of Covey's Win/Win recommendation in which he emphasizes the importance of seeking a mutual benefit. 
Additionally, Haleblian and Finkelstein [36] find (dominant) CEOs who restrict information in turbulent environments actually perform worse than those who do not. Their study concludes information flow between leader and follower is severely hampered due to the followers' fears of conflicting a dominant leader. This follows Covey's thought process in suggesting a Win/Win situation (building interpersonal channels of communication) leads to a more effective leader.

Tyagi [37] finds employees (in sales) view leadership behavior whose ideas are taken into consideration when designing job descriptions and performance measures to evaluations are significant. Employees' views of leadership are significant in the outcome of motivation and better job performance. This idea of motivation to do a better job stems from the interpersonal relationship and Win/Win behavior of an effective leader, thus support for Covey's habit. Interpersonal relationships between leader and follower are strongly suggested in previous literature [30,3843]. While extant charismatic literature generally focuses on a leader driven relationship [14,39,44-47]. Howell and Shamir [48] point decidedly to a mutually beneficial relationship between leader and follower, where the empowered follower influences the leader [49]. This all points to the idea of a mutually beneficial relationship where both parties are thinking Win/Win.

\section{Habit 5: Seek first to understand, then to be understood-prin- ciples of empathetic communication}

Communication is a key component to all human interaction. Covey [10] emphasizes this habit by stressing the importance of not only reading and writing, but also of speaking and listening. All four of these components and doing them well are essential to effective leadership. Covey is quick to point out that to interact effectively, a leader needs to understand technique is not as critical as character, and character reveals an individual's true intentions. Listening to others becomes central to understanding. Covey defines listening as not merely hearing words spoken in order to reply; rather, it is a much deeper definition. It is an understanding that listening involves an intent to understand the other person. Covey refers to this type of listening as empathetic listening, or a deeper understanding of where the other individual's frame of mind resides. Problems cannot be solved effectively without truly understanding the task at hand, which is conveyed from one person to another (listening). Covey emphasizes the first part of the equation is to understand, but the other part of the equation (equally important) is to be understood. Part of this equation is predicated on respect (mutual), but it also relies on courage (leader).

Ashley and Patel [29] find quality of management is a significant attribute of successful leaders. In defining quality of management, they measure the ability to communicate. They argue this characteristic is essential to relaying vision to the company, as well as a recruitment tool used to attract the best talent with which to build teams.

Tyagi [37] finds the degree with which subordinates feel leaders recognize and convey their problems and successes to upper level management have a significant outcome on performance. This is a direct reflection of two-way communication, and a result of effective leadership [21,50-55]. Extant literature attempts to break down communication further than just an interpersonal behavior [56- 67], but the idea remains the same: communication is an important characteristic of effective leadership. This habit is also a core component in ethical leadership theory, authentic leadership theory, transformational leadership theory, servant leadership theory, and leader-member exchange theory.

\section{Habit 6: Synergize-principles of creative cooperation}

Covey [10] defines synergy as the highest form of the previous habits combined. The elements of personal responsibility (proactivity), visualization (begin with the end in mind), personal management (first things first), interpersonal interdependence (think win/win), and communication (seek first to understand, then to be understood) all contribute to the focus of a principle centered, effective leadership habit, defined as synergy. All the previous habits build on each other, culminating in an effect where the whole is greater than the summation of each of the individual parts. This habit of effective leaders permeates to all facets of life, particularly through communication (open mindedness) and business (creativity), whereas the opposite effect of negativity reflects itself synergistically through a narrow mindedness reality of control or unhealthy dependence (as opposed to interdependence). Covey emphasizes the importance of this habit by suggesting a person accessing intuition, creativity and visual insight (right brain activity) as well as the analytical, logical, and verbal characteristics of the left brain, is only working properly when the brain is functioning in its entirety (synergy). He continues that the reality of life is not just logical, nor is it only emotional. It is a combination of the two, or simply, we all live in a synergistic reality.

Covey suggests synergy is a combination of the previous habits but is culminated in a situation leading to open-mindedness and creativity. Bass, Waldman, Avolio, and Bebb [16] suggest this same concept when looking at charisma. They conclude an effective leader stimulates the intellect of followers by encouraging them to look at problems differently and 'thinking outside of the box' (creative mentality).

Previous research emphasizes this idea of creativity and its importance in creating and sustaining competitive advantages [68-73]. Additionally, Covey's idea of synergy within the context of creativity in the workplace is further supported by studies highlighting the contributions of employees to their organizations [74-78] and the expected leadership that empowers such employees [79-84] Creativity is also a core component of the servant and transformational leadership theories.

\section{Habit 7: Sharpen the saw-principles of balanced self-renewal}

Covey [10] concludes his seven habits of highly effective people by eluding to the need of renewal. However, in typical Covey fashion, it is a multi-step process in which several areas of an individual life will be impacted: physical, social/emotional, spiritual, and mental. Each area has different characteristics and must be attended to in order to enhance the very characteristics which define an individual. The physical dimension seeks to care or renew the body through exercise (regularly), nutrition (eating healthy) and effective stress management. The social or emotional dimension relates to service (to others), empathy (towards others), synergy (with life's reality), and intrinsic security. The spiritual dimension is an individual understanding of core values (value clarification), commitment, study (personal development) and meditation (calmness). The mental dimension is renewal through reading, visualizing, planning and writing. These balanced approaches revolve around the previous habits but need continual attention for an effective leader to remain 'sharp.'

While there have been numerous studies done on the idea of balance in a working professional's life $[85,86]$, there has been little study on balance within the realm of leadership. Additional research on balance within the employees' life and work environment cover every discipline from economics to sociology [87-102], thus further 
stressing its importance. While the outcome of these studies has proven inconclusive for effective employee or organizational performance, there are other avenues through which balance seemingly permeates to better production.

\section{Discussion}

This exhaustive review of the literature to find support or lack thereof for Covey's habits found that none of the studies set out to validate the holistic set of habits. Covey makes no reference to outside resources, but rather draws on personal knowledge and learning in writing his framework. This table compares and annotates the characteristics of Stephen R. Covey's 7 Habits of Highly Effective People with the 5 major leadership theories. The 5 major leadership theories include: Ethical Leadership Theory, Authentic Leadership Theory, Transformational Leadership Theory, Servant Leadership Theory, and Leader-Member Exchange Theory (LMX).

Table 1 outlays the seven habits Covey expresses as the fundamental traits effective people should display, along with whether there is support from the five leading leadership theories. Are these habits central to current leadership theory in management? There is moderate support in the literature for most of the habits, but lacking support in habit three: Put First Things First (or prioritization). That is not to suggest that setting priorities is not supported in the literature, rather that the five leading theories of leadership do not carry that 'habit' as a main characteristic of the theory. Both relationship and communication habits as Covey suggests are clearly supported in all theories, which intuitively are building blocks to effective leadership.

While most of the habits are in some form or fashion associated with effective leadership, the leadership literature is very exhaustive with different theories and types of leaders, each having unique characteristics or tendencies that can be applicable to Covey's habits. All the habits are supported in the leadership literature except for the final habit of 'Sharpening the Saw' where the concept is physical, emotional and spiritual balance. Ethical leadership theory, authentic leadership theory, and transformational leadership theory are loosely associated with balance (as indicated in Table 1) but could not be conclusively classified as a core component of those theories. Extant leadership literature has not addressed this idea and is severely lacking in this area. However, there is considerable literature in discussing a balanced life within the work place. Further studies have the potential to survey leaders and the balance in which they possess within their work

\begin{tabular}{|c|c|c|c|c|c|}
\hline \multirow{2}{*}{$\begin{array}{c}\text { Leadership } \\
\text { Characteristics } \\
\text { Covey's } 7 \text { Habits }\end{array}$} & \multicolumn{5}{|c|}{ Leadership Theories } \\
\hline & Ethical & Authentic & Transformational & Servant & LMX \\
\hline $\begin{array}{l}\text { Proactive (Drive/ } \\
\text { Motivation) }\end{array}$ & $x$ & -- & $x$ & -- & -- \\
\hline $\begin{array}{l}\text { Begin with the End in } \\
\text { Mind (Visionary) }\end{array}$ & -- & -- & $x$ & $\mathrm{x}$ & -- \\
\hline $\begin{array}{l}\text { Put First Things First } \\
\text { (Prioritization) }\end{array}$ & -- & -- & -- & -- & -- \\
\hline $\begin{array}{l}\text { Think Win/Win } \\
\text { (Relationship) }\end{array}$ & $x$ & $x$ & $x$ & $x$ & $\mathrm{x}$ \\
\hline $\begin{array}{l}\text { Seek First } \\
\text { to Understand, } \\
\text { Then Understood } \\
\text { (Communication) }\end{array}$ & $x$ & $x$ & $x$ & $x$ & $\mathrm{X}$ \\
\hline Synergize (Creativity) & -- & -- & $x$ & $x$ & -- \\
\hline $\begin{array}{l}\text { Sharpen the Saw } \\
\text { (Life Balance) }\end{array}$ & $x$ & $x$ & $x$ & -- & -- \\
\hline
\end{tabular}

Table 1: Leadership characteristics comparison with Covey's 7 habits. lives and non-work lives to study what mediators and or moderators influence their productivity or effectual leadership.

\section{Conclusion}

Covey is very optimistic about the outcome of following the habits in becoming an effective individual. However, subscribing to these habits could have a negative impact on management. Different characteristics of proactivity could lead one to be overly aggressive, alienating others. Too much time spent on visionary prowess could lead to day-dreaming and lacking focus. Prioritizing the wrong principles could lead others and ultimately the organization to disaster. Too much time spent on relationships (building and maintaining) could take away time for other, more productive activities. Communication is assumed to be positive or productive, but negative communication is dangerous. Too much creativity lacks vision and focus. There is no standard for balance, or an optimal work/non-work formula. Individuals, thinking themselves balanced, could be spending too much time outside of productive activities, leading to unproductive behavior. Covey's habits are indeed helpful in guiding others to be effective. However, the inherent danger is that being effective and leading others carries an ethical responsibility. History is littered with examples of leaders who were effective, but misguided. An effective leader with misguided priorities can have damaging effects, not only on followers, organizations, cultures or countries, but also globally.

\section{References}

1. Lord R, De Varder C, Alliger G (1986) A meta-analysis of the relation between personality traits and leadership perceptions: An application of validity generalization procedures. J Appl Psychol 71: 402-410.

2. Kirkpatrick SA, Locke EA (1991) Leadership: Do traits matter. Acad Manage Exe 5: 48-60.

3. Tannenbaum R, Schmidt W (1973) How to choose a leadership pattern. Harvard Bus Rev 51: 162-180.

4. Goleman D (2000) Leadership that gets results. Harvard Bus Rev 78: 78-90.

5. Podsakoff PM (1982) Determinants of a supervisor's use of rewards and punishment: A literature review and suggestions for future research. Organ Behav Hum Perform 29: 58-83.

6. Yukl GA (2012) Effective leadership behavior: What we know and what questions need more attention. Acad Manage Perspect 26: 66-85.

7. Biggart NW, Hamilton GG (1984) The power of obedience. Admin Sci Quart 29: $540-549$

8. Brown M, Trevino L, Harrison D (2005) Ethical leadership: A social learning perspective for construct development and testing. Organ Behav Hum Decis Process 97: 117-134

9. Judge TA, Bono JE, Ilies R, Gerhardt M (2002) Personality and leadership: A qualitative and quantitative review. J Appl Psychol 87: 765-780.

10. Covey SR (1989) The 7 habits of highly effective people: Powerful lessons in personal change.

11. Stogdill RM (1974) Handbook of leadership: A survey of the literature. Free Press, New York, USA

12. Stogdill RM (1948) Personal factors associated with leadership: A survey of the literature. J Psychol 25: 35-71.

13. House RJ, Aditya RN (1997) The social scientific study of leadership: Quo vadis?. J Manage 23: 409-473.

14. Yukl GA (1998) Leadership in organizations (4th edn), Upper Saddle River, Prentice-Hall, NJ, USA. pp: 80-114.

15. Burns JM (1978) Leadership. Harper \& Row, New York, USA.

16. Bass BM, Waldman DA, Avolio BJ, Bebb M (1987) Transformational leadership and the falling dominoes effect. Group Organ Stud 12: 73-87. 
17. Bass BM (1985) Leadership and performance beyond expectations. Free Press, New York, USA. Hum Resour Manage 25: 481-484.

18. Bennis W, Nanus B (1985) Leaders: The strategies for taking charge.Harper and Row, New York, USA. Hum Resour Manage 24: 503-508.

19. Conger JA (1989) The charismatic leader: Behind the mystique of exceptional leadership. Jossey-Bass, San Francisco, USA. pp: 140-170.

20. Baum JR, Locke EA, Kirkpatrick S (1998) A longitudinal study of the relation of vision and vision communication to venture growth in entrepreneurial firms. $J$ Appl Psychol 83: 43-54

21. Awamleh R, Gardner WL (1999) Perceptions of leader charisma and effectiveness: The effects of vision content, delivery and organizational performance. Leadership Quart 10: 354-373.

22. Strange JM, Mumford MD (2002) The origin of vision: Charismatic versus ideological leadership. Leadership Quart 13: 343-377.

23. Avolio BJ, Zhu W, Koh W, Bhatia P (2004) Transformational leadership and organizational commitment: Mediating role of psychological empowerment and moderating role of structural distance. J Organ Behav 25: 951-968.

24. Elenkov DS, Judge W, Wright $P$ (2005) Strategic leadership and executive innovation influence: An international multi-cluster comparative study. J Strategic Manage 26: 665-682.

25. Groves KS (2006) Leader emotional expressivity, visionary leadership, and organizational change. J Leadership Organ Dev 27: 566-583.

26. David GB, Sexton DL (1988) An interactive model of new venture initiation. $J$ Small Bus Manage 26: 1-7.

27. Spears L (1995) Servant-leadership and the Greenleaf legacy. In: Reflections on leadership: How Robert K. Greenleaf's theory of servant-leadership influenced today's top management thinkers, Spears, L. (Ed), John Wiley \& Sons, New York, USA. pp: 1-14

28. Yukl GA (1994) Leadership in organizations (7th edn), Prentice Hall, London, UK. pp: 25-54.

29. Ashley A, Patel J (2003) The impact of leadership characteristics on corporate performance. Int J Value Based Manage 16: 211-222.

30. Graen GB, Bien UM (1995) Relationship-based approach to leadership: Development of leader-member exchange (LMX) theory of leadership over 25 years: Applying a multi-level, multi-domain perspective. Leadership Quart 6: 219-247.

31. Schriesheim CA, Castro SL, Cogliser CC (1999) Leader-member exchange (LMX) research: A comprehensive review of theory, measurement and dataanalytic practices. Leadership Quart 10: 63-113.

32. Ehrhart GM (2004) Leadership and procedural justice climate as antecedents of unit-level organizational citizenship behavior. Pers Psychol 57: 61-94.

33. Hill K (2003) Development of leadership competencies as a team. J Nurs Adm 33: 639-642.

34. Pettigrew AM (1972) Information control as a power resource. Sociol 6: 187-204.

35. Mechanic D (1962) Sources of power of lower participants in complex organizations. Admin Sci Quart 7: 349-364.

36. Haleblian J, Finkelstein S (1993) Top management team size, CEO dominance, and firm performance: the moderating roles of environmental turbulence and discretion. J Acad Manage 36: 844-863.

37. Tyagi PK (1985) Relative importance of key job dimensions and leadership behaviors in motivating salesperson work performance. J Market 49: 76-86.

38. Meindl JR, Long KM (1990) On leadership: An alternative to the conventional wisdom. Res Organ Behav 12: 159-203.

39. Yukl GA, Fleet VDD (1992) Theory and research on leadership in organizations. In: Dunnette MD, LM Hough (Eds). Handb Ind Organ Psychol (2nd edn) 1: 147-197.

40. Hollander EP (1993) Legitimacy, power and influence: A perspective on relational features of leadership. In Chemers MM, Ayman R (Eds). Leadership Theory Res Perspect Dir 1: 29-48.

41. Jermier JM (1993) Introduction: Charismatic leadership: Neo-weberian perspectives. Leadership Quart 4: 217-234.

42. Klein KJ, House RJ (1995) On fire: Charismatic leader ship and levels of analysis. Leadership Quart 6: 183-198.
43. Meindl JR (1995) The romance of leadership as a follower centric theory: A social constructionist approach. Leadership Quart 6: 329-341.

44. House RJ (1977) A 1976 theory of charismatic leadership. In Hunt JG, Larson LL (Eds). Leadership: Cutting Edge 1: 189-207.

45. Conger JA, Kanungo RN (1998) Charismatic leadership in organizations, Thousand Oaks, Sage, CA, USA. pp: 121-189.

46. Beyer JM (1999) Two approaches to studying charismatic leadership: Competing or complementary?. Leadership Quart 10: 575-588.

47. Lord RG, Brown DJ, Freiberg SJ (1999) Understanding the dynamics of leadership: The role of follower self-concepts in the leader/follower relationship. Organ Behav Hum Decision Processes 78: 167-203.

48. Howell JM, Shamir B (2005) The role of followers in the charismatic leadership process: Relationships and their Consequences. Acad Manage Rev 30: 96-112.

49. Dvir T, Avolio BJ, Shamir B (1998) Impact of transformational leadership on follower development and performance: A field experiment. Acad Manage 45 735-744.

50. Spangler WD, House RJ (1991) Presidential effectiveness and the leadership motive profile. J Pers Soc Psychol 60: 439-455.

51. Kirkpatrick SA, Locke EA (1996) Direct and indirect effects of three core charismatic leadership components on performance and attitudes. J App Psychol 81: 36-51.

52. Hartog DN, Verburg RM (1997) Charisma and rhetoric: Communicative techniques of international business leaders. Leadership Quart 8: 355-391.

53. Frese M, Beimel S, Schoenborn S (2003) Action training for charismatic leadership: Two evaluations of studies of a commercial training module on inspirational communication of a vision. Pers Psychol 56: 671-698.

54. Riggio RE, Riggio HR, Salinas C, Cole EJ (2003) The role of social and emotional communication skills in leader emergence and effectiveness. Group Dynam Theor Res Prac 7: 83-103.

55. Towler AJ (2003) Effects of charismatic influence training on attitudes, behavior and performance. Pers Psychol 56: 363-381.

56. Leary T (1957) Interpersonal diagnosis of personality; a functional theory and methodology for personality evaluation. Ronald Press, Oxford, UK. pp: 91-154.

57. Norton RW (1978) Foundation of a communicator style constructs. Hum Commun Res 4: 99-112.

58. Wiemann J, Chen V, Giles H (1986) Beliefs about talk and silence in cultural context. Paper presented at the Speech communication association convention Chicago, USA.

59. Hansford BC, Hattie JA (1987) Perceptions of communicator style and selfconcept. Commun Res 14: 189-203.

60. Sorenson RL, Savage GT (1989) Signaling participation through relationa communication: A test of the leader interpersonal influence model. Group Organ Stud 14: 325-354.

61. Butterfield BM, Butterfield BS (1990) Conceptualizing affect as information in communication production. Hum Commun Res 16: 451-476.

62. Singelis TM (1994) The measurement of independent and interdependent selfconstruals. Pers Soc Psychol Bull 20: 580-591.

63. Gudykunst WB, Matsumoto Y, Toomey TS, Nishida T, Kim K, et al. (1996) The influence of cultural individualism-collectivism, self-construal's, and individual values on communication styles across cultures. Hum Commu Res 22: 510-543.

64. McCroskey JC, Daly JA, Martin MM, Beatty MJ (1998) Communication and personality: Trait perspectives, (215-231). Cresskill, Hampton Press, Inc, NJ, USA.

65. Dillard JP, Solomon DH, Palmer MT (1999) Structuring the concept of relational communication. Commun Monogr 66: 49-65.

66. Daft RL (2003) Management (6th edn), Southwestern Cincinnati, OH, USA pp: 7-27).

67. McCartney WW, Campbell CR (2006) Leadership, management, and derailment: A model of individual success and failure. Leadership Organ Dev 27: 190-202.

68. Drucker PF (1985) Innovation and entrepreneurship: Practice and principles Harvard Bus Rev 10: 105-109.

69. Woodman RW, Sawyer JE, Griffin RW (1993) Toward a theory of organizational creativity. Acad Manage Rev 18: 293-321. 
Citation: Spohn D (2018) An Operational Definition of Effective Leadership: Was Covey Right?. Review Pub Administration Manag 6: 251. doi:10.4172/2315-7844.1000251

70. Amabile TM (1996) Creativity in context: Update to the social psychology of creativity. Westview Press, Boulder, CO, USA.

71. Tierney P, Farmer SM, Graen GB (1999) An examination of leadership and employee creativity: The relevance of traits and relationships. Pers Psychol 52: $591-620$.

72. Jung DI, Chow C, Wu A (2003) The role of transformational leadership in enhancing organizational innovation: hypotheses and some preliminary findings. Leadership Quart 14: 525-544.

73. Shalley CE, Zhou J, Oldman GR (2004) The effects of personal and contextual characteristics on creativity: Where should we go from here?. J Manage 30: 933-958.

74. Amabile TM (1988) A model of creativity and innovation in organizations. In Staw BM, Cummings LL (Edn). Res Organ Behav 10: 123-167.

75. Shalley CE, Gilson LL, Blum TC (2000) Matching creativity requirements and the work environment: Effects on satisfaction and intent to leave. J Acad Manage 43: 215-223

76. Madjar N, Oldham GR, Pratt MG (2002) There's no place like home? The contributions of work and nonwork creativity support to employee's creative performance. J Acad Manage 45: 757-767.

77. Zhou J, Shalley CE (2003) Research on employee creativity: A critical review and directions for future research. In Martocchio JJ (Eds). Res Pers Hum Resour Manage 22: 165-217.

78. Shalley CE, Gilson LL (2004) What leaders need to know: A review of social and contextual factors that can foster or hinder creativity. Leadership Quart 15: 33-53.

79. Amabile TM, Conti R, Coon H, Lazenby J, Herron M (1996) Assessing the work environment for creativity. J Acad Manage 39: 1154-1184.

80. Thomas KW, Velthouse BA (1990) Cognitive elements of empowerment: An "interpretive" model of intrinsic task motivation. Acad Manage Rev 15: 666-681.

81. Kirkman BL, Rosen B (1997) A model of work team empowerment. In Woodman RW, Pasmore WA (Edn). Res Organ Change Dev 10: 131-167.

82. Zhou J (1998) Feedback valence, feedback style, task autonomy, and achievement orientation: Interactive effects on creative performance. J Appl Psychol 83: 261-276.

83. Kirkman BL, Rosen B (1999) Beyond self-management: Antecedents and consequences of team empowerment. J Acad Manage 42: 58-74.

84. Amabile TM, Schatzel EA, Moneta GB, Kramer SJ (2004) Leader behaviors and the work environment for creativity: Perceived leader support. Leadership Quart 15: 5-32.

85. Rapoport R, Bailyn L, Fletcher JK, Pruitt BH (2002) Beyond work-family balance: Advancing gender equity and workplace performance. Jossey-Bass, San Francisco, CA, USA. 39: 5839-5897.
86. Estes SB, Michael J (2005) Work-family policies and gender inequality at work A Sloan work and family encyclopedia entry.

87. Nelson DL, Quick JC, Hitt MA, Moesel D (1990) Politics, lack of career progress and work/home conflict: Stress and strain for working women. Sex Rol 23: 169-185.

88. Frolick MN, Wilkes RB, Urwiler R (1993) Telecommuting as a workplace alternative: an identification of significant factors in American firms determination of work-at-home policies. J Strategic Inform Syst 2: 206-220.

89. Johnson BN, Provan GK (1995) The relationship between work/family benefits and earnings: A test of competing predictions. J Soc Econ 24: 571-584.

90. Raabe PH (1996) Constructing pluralistic work and career arrangements. In S. Lewis \& J. Lewis (Eds), The work-life challenge: Rethink Employ 128-141. Sage, London, UK.

91. Glass J, Estes S (1997) The family responsive workplace. Ann Rev Sociol 23 289-313.

92. Allen TD, Russell JE (1999) Parental leave of absence: Some not so family friendly implications. J Appl Soc Psychol 29: 166-191.

93. Whitehouse G, Zetlin D (1999) Family friendly policies: Distribution and implementation in Australian workplaces. Econ Labour Relat Rev 10: 221-239.

94. Konrad A, Mangel R (2000) The impact of work-life programs on firm productivity. J Strategic Manage 21: 1225-1237.

95. Smith PJE, Blum TC (2000) Work-life human resource bundles and perceived organizational performance. J Acad Manage 43: 1107-1117.

96. Hill EJ, Hawkins AJ, Ferris M, Weitzman M (2001) Finding an extra day a week: The positive influence of perceived job flexibility on work and family life balance. Fam Relat 50: 49-58.

97. Loy BM, Wharton AS (2002) Employees' use of work-family policies and the workplace social context. Soc Forces 80: 813-845.

98. Hegtvedt K, Warner CJ, Ferrigno E (2002) Reactions to injustice: Factors affecting workers' resentment toward family-friendly policies. Soc Psychol Quart 65: 386-400.

99. Baines S, Gelder U (2003) What is family friendly about the workplace in the home? The case of self-employed parents and their children. New Technol Work Employ 18: 223-234.

100. Batt R, Valcour PM (2003) Human resources practices as predictors of workfamily outcomes and employee turnover. Ind Relat 42: 189-220.

101. Eaton SC (2003) If you can use them: Flexibility policies, organizational commitment, and perceived performance. Ind Relat 42: 145-167.

102. Wayne JH, Cordeiro BL (2003) Who is a good organizational citizen? Social perception of male and female employees who use family leave. Sex Role 49: $233-246$. 